\title{
Analysis on Western Universal Value Theory
}

\author{
Sang Jiang \\ Liao Ning Urban Construction Technical College, \\ ShenYang, Liaoning, 110122
}

\begin{abstract}
Wrapped in academic discourse, Western universal values theory advocates political discourse and political system with strong imprint of western institutions disseminating by the form of public discourse. It shows a rebound trend, after a decline in our country. In the critical period of the current economic and social development, we must be vigilant and stop the spread of this trend and identify its deceptive and harmful feature, preventing its penetration into the masses so that we can focus on developing socialism with Chinese characteristics to cope with serious challenges that it would bring.
\end{abstract}

Key Words- Western universal values theory; Socialist core values; Socialism with Chinese characteristics

\section{INTRODUCTION}

Western universal value theory is not a simple academic concepts and its related controversy involves in our country's ideological security and socialist orientation for development. Using the Marxist stand, viewpoint and method to respond for us to clarify wrong concepts is of great significance for ensuring the correct direction of socialism with Chinese characteristics. Western universal value theory advocates the existence of universal human values, essentially considering the values of Western countries as a universal human pursuit of eternal value, to which we should consciously boycott and insist on the belief of building socialism with Chinese characteristics cause.

\section{Status of Western universal value theory}

"Universal value" means blindly copy the value system of other country advocating the socalled western "freedom, democracy, equality and human rights" and other values, ignoring the specificity and uniqueness of their own development. It advertises itself as the universal values of human society and turns to attack Chinese current political system. It is directly aimed at advocating political discourse and system which has a strong imprint of western institutions, wrapping in academic discourse through spread of academic discourse.

In recent years, some remarks promoting western "universal value" make a great clamor, trying to infiltrate socialist discourse system of the eighteenth session of the National People's Congress with western abstract "freedom, democracy, equality, human rights" concept and distort the contents of the socialist core values. It is said: four "advocates" which is put forward in the report of the eighteenth session of the National People's Congress " lists universal values in the scope of socialist core values". Some people say some new formulations in the eighteenth session of the National People's Congress worth attention, among which the largest highlight is listing democracy, freedom, equality, justice and other universal values in the socialist core values, marking that the Chinese Communist Party ideologically begin to move closer to a modern society. "1. Such remarks lead to a rebound trend of west universal values after a decline in China.

Reason of the trend lies in that since the reform and opening up policy, the successful practice and great achievements of socialism with Chinese characteristics build a strong 
foundation of path confidence, theory confidence and institutional confidence. The penetration and evolution of a variety of western erroneous ideas in economic, political and historical fields have been difficult to achieve its purpose. In this case, the western universal value is forced to find a breakthrough in value and the western hostile forces also take the opportunity to reverse the direction of refining socialist values."

And the deeper reason is on the one hand closely related to "bourgeois liberalization" thought in process of China's reform and opening. Some people focus on problems in the advance process of socialist cause under the influence of western bourgeoisie value and theoretical system, advocating abstract humanitarianism, neo-liberalism. They look at the history of the socialism practice and revaluate all values in an attempt to completely negate Marxism. On the other hand, some people do not resist temptations in the process of development of the socialist market economy and lost position between the interests and socialist ideals and beliefs turning to Western thought.

\section{Characteristics in the spread of western universal value}

\subsection{Aiming at deceiving the word}

Nowadays western universal value theory is a product of western contemporary nonideological thought. In the process of theory promotion and construction, it emphasizes the commonality of human nature and values standard and deny human class and historic nature. This theory concretizes concepts of freedom, democracy, equality and human rights considering that what they preach is universal value, and avoid the materiality of those values and regard capitalist system as the best system in human society. It emphasizes capitalism civilization is the ultimate insurmountable human civilization and think that only capitalism can guarantee the realization of these values. Its essence is to destroy the fortress of socialist ideology and system of values and promote convergence of world social system. It is particularly outstanding on Western countries' attitude on China's performance. In their view, different from Western values, values inherited from ancient times do not have any universal applicability. The former US President Bill Clinton once said, America's goal is to establish a "democratic and prosperous world," and will spare no efforts to promote "democratic state system" and "free institutions" to the world and China, reshaping the world with Western values.

Currently, some people are in blind pursuit of western theory advocate the western universal value theory without knowing essence and truth of things from the surface of the text and abstract concept of freedom, democracy, equality and human rights. Moreover they equal the good things in human civilization to universal value, ignoring regularity of freedom, democracy, equality, the concept of justice in the ideological connotation and regulations of laws of socialism and forcibly mix with the concept advocated by the west. Its essence is to negate practice,theory and established system of Chinese tradition and Marx Marxism Chinesization acting as guardians of western ideology.

\subsection{Taking measures of hot news speculation}

Based on western values, western universal values hype universality of western values with the help of social hot news. In 2012, when Mo Yan won the Nobel Prize for Literature, the foreign media remarked "he should be seen as a model of Chinese writer's communicating with universal civilization". There are also some Chinese scholars agreed "suffering, humanity, love, understanding and tolerance are Mo Yan's speech keywords and he used this to join worldwide universal values ". In 2013, Chinese reform step into the key stage. As for questions appeared in China's economic development, 
some people advocate only accepting the "universal values", Chinese second reform could have a future. The development of Chinese economy and society must move forward to the "universal values" and values implied in Chinese model have a profound "ideological" characteristics while Chinese modernization must "uphold universal values." In 2014, in the event of Hong Kong's illegal "Zhan Zhong", some people ignore proven success of "one country two systems", advocating Hong Kong "anti-mainland" sentiment so as to interfere in Hong Kong affairs.

\section{Keep an eye on the rebound of western universal value theory}

In the context of economic globalization, the Western hostile forces advocate freedom, democracy, equality and human rights under the background of Western society and carry out culture "neo-interventionism". Its essence is to guide public opinion without restraint and disrupt economic and social development of guidance thought and the socialist orientation to interfere socialist modernization process for the purpose of achieving the goal of safeguarding western interests. Some domestic scholars advocate the western universal value theory and try in vain to solve problems appeared in the process of development of Chinese social reform by wholesale acceptance of Western culture to, which is actually a serious cultural anxiety and non confidence. In the critical period of China's economic and social development, we must be vigilant and stop the spread of this trend, promoting mainstream ideology construction and improve the political discernment to recognize the essential attribute of consciousness. Also we should strengthen the ideal and faith education and socialism with Chinese characteristics education, in particular to strengthen education form of the socialist core values and highlight the theme of education as well as innovating advocacy methods and seizing the public speaking right against the penetration of universal values into the masses. Fundamentally speaking, only coping well with our own affairs can we really deal with serious challenge of universal values. Only we concentrate on our own development would universal values collapse without being attacked. 4.1 Insist on correct public opinion guidance

Since the eighteenth session of the National People's Congress, the socialist core values provide a powerful ideological weapon against Western "universal values". On one hand, we must actively preach to explain theoretical perspective and practice attributes contained in socialist value system to provide strong theoretical support and ideological guarantee for resisting the erroneous ideas and spreading the socialist core values. We should adhere to combine the socialist core values education with Chinese dream publicity and education and combine the basic requirements of the socialist core values with the actual specific work so as to actively practice the core values in the modern practice in China to the extent of matching words with deeds. On the other hand, concentrate efforts to the "three close". We should actively use the news media, the Internet and other communication carriers to create atmosphere of the mainstream media so that social morality of all for one, one for all and social atmospherethe advocating ethics and doing good turns can take shape. It can really bring socialist core values into the ear, into the brain, into the heart and strengthen main public opinion environment of socialist core values.

\subsection{Create a new situation in building the socialist cause with Chinese characteristics}

Comrade Deng Xiaoping's socialist modernization blueprint for us is becoming a bright reality step by step. Our great motherland is more and more prosperous and strong day by day and the Chinese nation is step by step toward road of great rejuvenation. In this process, there are still unsatisfactory in our democracy rule of law, fairness and justice, freedom and equality, however, nowadays China's rapid development has won the respect 
of most of the world, highlighting the era value of China model values, indicating that the socialist system with Chinese characteristics designed for human development and progress issue has unique advantages.

\section{Conclusion}

Therefore, if we insist in the value of socialism with Chinese characteristics and steadily advance the cause of socialism with Chinese characteristics in the common globalization, concentrating on developing its own, western "universal values" eventually will fall into decline.

\section{Acknowledgment}

This article is the phased objectives of Niaoning Social sciences planning project in
2013 Critical Studies on Western Universal Value, project leader: Sang Jiang, project number:L13BZX006

\section{References}

[1] Hou Huiqin, Explain the mystery of universal value, People's Tribune,2014 (04)

[2] Tang Liru, Discourse paradigm of initiative transcending universal value, Theory Guide,2014(06)

[3] Luo Jianwen, Zhao Change, Discussion guideline of The value of socialism with Chinese characteristics confidence, Journal of Yanan Cadre College of China,2014 (03) 